\title{
Physiological variables and egg quality from quails (Coturnix coturnix japonica) that received water with increasing levels of $\mathrm{NaCl}$ and under different temperatures
}

\section{Variáveis fisiológicas e qualidade de ovos de codorna (Coturnix coturnix japonica) que receberam água com teores crescentes de $\mathrm{NaCl}$ e sob diferentes temperaturas}

\begin{abstract}
Ladyanne Raia Rodrigues ${ }^{1 *}$; Dermeval Araújo Furtado2; Valéria Pereira Rodrigues"; Patrício Gomes Leite'; Neila Lidiany Ribeiro3; Cleber Franklin Santos de Oliveira4; Soahd Arruda Rached Farias²; Thiago Galvão Sobrinho ${ }^{5}$
\end{abstract}

\section{Highlights}

The Increasing levels of TDS in water has not affected the animal performance.

The water with TDS does not alter the eggs' quality.

Japanese quails can consume water with salinity levels of up to $6.0 \mathrm{dS} \mathrm{m}^{-1}$.

\section{Abstract}

The objective of this study was to evaluate the influence of water salinity and ambient temperature on the physiological variables and the quality of Japanese quail eggs (Coturnix coturnix japonica) in the laying phase. The quails received water with increasing levels of salinity $\left(1.5,3.0,4.5\right.$ and $\left.6.0 \mathrm{dS} \mathrm{m}^{-1}\right)$ and were kept in climatic chambers under two different temperatures $\left(24^{\circ} \mathrm{C}\right.$ and $\left.32^{\circ} \mathrm{C}\right)$. The design used was completely randomised, with a $2 \times 4$ factorial arrangement (temperatures and salinity levels), with six replicates of eight birds each. Data were submitted for analysis of variance and the means were compared by the Tukey test at $5 \%$. There was no influence $(P>0.05)$ of water salinity levels on the physiological variables nor on the quality of the birds' eggs. At $32^{\circ} \mathrm{C}$ there was an increase $(P<0.05)$ in respiratory rate, cloacal and body surface temperature of the birds, and a slight reduction $(P<0.05)$ in the weight of eggs, shells, and percentage of

1 Doctors, in Agricultural Engineering, Universidade Federal de Campina Grande, UFCG, Campina Grande, PB, Brazil. E-mail: ladyannezootecnia@hotmail.com; valeriazootecnia@hotmail.com; pgomesleite@gmail.com

2 Profs., Head of the Agricultural Engineering Academic Unit, UFCG, Technology and Natural Resources Center, Campina Grande, PB, Brazil. E-mail: araujodermeval@gmail.com; soahd.rached@gmail.com

${ }_{3}^{3}$ Scholarship PCI/CNPq, Instituto Nacional do Semi-Árido, Campina Grande, PB, Brazil. E-mail: neilalr@hotmail.com

4 Prof., Universidade Federal do Mato Grosso, UFMT, Cuiabá, MT, Brazil. E-mail: c_f_s_o@hotmail.com

${ }_{5}^{5}$ Master in Agricultural Engineering, UFCG, Campina Grande, PB, Brazil. E-mail: tgs_galvao@hotmail.com

* Author for correspondence

Received: Mar. 29, 2021 - Approved: June 14, 2021 
shell. For laying quails, water with salinity levels of up to $6.0 \mathrm{dSm}^{-1}$ can be used and the birds can be raised in an environment with temperatures up to $32^{\circ} \mathrm{C}$.

Key words: Ambience. Physiological variables. Saline water. Quail raising.

\section{Resumo}

O objetivo do trabalho foi avaliar a influência da salinidade da água e da temperatura ambiente nas variáveis fisiológicas e na qualidade dos ovos de codornas japonesas (Coturnix coturnix japonica) na fase de postura, recebendo água com níveis crescentes de salinidade $(1,5,3,0$, 4,5 e 6,0 dS m-1), e mantidos em câmaras climáticas sob duas temperaturas diferentes $\left(24\right.$ e $\left.32^{\circ} \mathrm{C}\right)$. $\mathrm{O}$ delineamento utilizado foi inteiramente casualizado, com arranjo fatorial 2x4 (temperaturas e níveis de salinidade), com seis repetições de oito aves cada. Os dados foram submetidos à análise de variância e as médias comparadas pelo teste de Tukey a $5 \%$. Não houve influência $(P>0,05)$ dos níveis de salinidade da água nas variáveis fisiológicas e na qualidade dos ovos das aves. $A 32^{\circ} \mathrm{C}$ houve um aumento $(P<0,05)$ na frequência respiratória, temperatura cloacal e da superfície corporal das aves e uma pequena redução $(P<0,05)$ no peso dos ovos, cascas e porcentagem da casca. Para codornas em postura pode-se utilizar água com salinidade de até $6,0 \mathrm{dSm}^{-1}$, podendo as aves ser criadas em ambiente com temperatura de até $32^{\circ} \mathrm{C}$.

Palavras-chave: Água salgada. Ambiente. Criação de codornas. Variáveis fisiológicas.

\section{Introduction}

Poultry farming is an expanding agricultural sector in all regions of Brazil. This is especially true in the semi-arid region, which has high temperatures, low humidity and low rainfall. Standing out in this region is the raising of quails for meat and eggs, due to the quails' adaptation to the environment, their precocity, production, low feed intake, and the small investment necessary for this activity (Guimarães et al., 2014; Ribeiro et al., 2016; Khalilipour, Maheri, \& Shaddel, 2019).

Quails are tolerant of heat conditions (Petrucci et al., 2017; Akdemir, Köseman, \& Şeker, 2019) however, as homeothermic birds, they need to maintain constant body temperature with a narrow range of variation (Ribeiro et al., 2016). They are ideal for maximising production when kept within their thermal comfort zone, which for adult quails should be temperatures between 18 and $26^{\circ} \mathrm{C}$ and relative humidity between 50 and $70 \%$ (S. M. Santos et al., 2014; El-Tarabany, 2016; Silva et al., 2017).

Quails raised under heat stress conditions modify their ingestive behaviour and trigger heat loss mechanisms, which can increase respiratory and heart rate, as well as cloacal and body surface temperature (Souza et al., 2013; Ribeiro et al., 2016; Rodrigues, Furtado, Costa, Nascimento, \& Cardoso, 2016), affecting animal welfare (T. C. Santos, Gates, Tinôco, Zolnier, \& Baêta, 2017) by compromising feed intake, assimilation, and metabolism, and causing a decrease in egg production, weight, and quality (Silva et al., 2017; Akdemir et al., 2019).

In arid and semi-arid regions, the water available to animals can contain high levels of salts (Abdelsattar, Hussein, Abd El-Ati, \& Saleem, 2020). The minerals in this water (such 
as chlorine, sodium, and potassium), which act in the balance of the body's acid-base homeostasis and the absorption of nutrients (such as amino acids), are fundamental to an animal's metabolism (Alahgholi, Tabeidian, Toghyani, \& Fosoul, 2014; Petrucci et al., 2017; Scottá et al., 2017).

Water consumption by quails is variable; it rises in hot climates to minimise the stress caused by thermal discomfort. It is ideal to provide birds with water with a salinity of up to $1.5 \mathrm{dS} \mathrm{m-1.} \mathrm{Quails} \mathrm{are} \mathrm{tolerant} \mathrm{of} \mathrm{the}$ consumption of more saline water (Raquel et al., 2011; Lima et al., 2015; Petrucci et al., 2017; Lima, Moraes, \& Barreto, 2020) but at high levels, metabolic and consumption alterations may occur, affecting the production and quality of eggs (Petrucci et al., 2017; Schneider et al., 2016). In addition, excessive intake of minerals increases water consumption and reduces the glomerular filtration rate in the kidneys, leading to increased renal excretion, which will be rich in minerals, such as sodium, chlorine and potassium (Freitas et al., 2013; Alahgholi et al., 2014).

The aim of this work was to evaluate the influence of increasing water salinity levels on physiological variables and the quality of the eggs of Japanese quails kept in a controlled environment under comfort and thermal stress.

\section{Material and Methods}

All procedures used were approved by the Animal Use Ethics Committee of the Federal University of Campina Grande (Protocol number 089.2017).

The experiment was carried out in two climatic chambers, with width, length and height dimensions of $3.07 \mathrm{mt} \times 2.77$ mt. x $2.60 \mathrm{mt}$. (Figure 1), located in the Rural Construction and Ambience Laboratory of the Federal University at Campina Grande, State of Paraíba, Brazil. For environmental control, the chambers were equipped with an electric resistance air heater, a hot/cold split air conditioner with a power of 18,000 BTUs, and an air humidifier with a capacity of $4.5 \mathrm{~L}$ and an average mist flow rate of $300 \mathrm{~mL}$ per hour. The relative humidity of the air was controlled by air humidifiers and measured by using sensors; the wind speed was obtained through side fans and exhaust fans. In addition, the chambers had interior temperature and humidity sensors. Environmental data were collected and recorded every 15 mins by sensors coupled to a data acquisition system, using an MT-530 PLUS controller from Full Gauge Controls $^{\circledR}$, controlled via computer throughSITRAD ${ }^{\circledR}$ (software for data acquisition, control, monitoring and visualisation inside the climatic chambers). For lighting in the chambers, 20W and 220V fluorescent lamps were used. Relative air humidity inside the climatic chambers was $65 \% \pm 5 \%$, throughout the experimental period, and the average wind speed was $2.0 \pm 0.5 \mathrm{~m} \mathrm{~s}^{-1}$.

Three hundred and eighty-four female Japanese quails (Coturnix coturnix japônica), at an average age of 14 weeks, were distributed in a completely randomised $2 \times 4$ factorial design, at two different temperatures $\left(24\right.$ and $32^{\circ} \mathrm{C}$ ) and four different levels of water salinity $\left(1.5,3.0,4.5\right.$ and $\left.6.0 \mathrm{dS} \mathrm{m}^{1}\right)$. A total of eight treatments with six replications, for eight birds per experimental unit, were submitted to a stocking rate of $206 \mathrm{~cm}^{2}$ bird $^{-1}$.

The nine-week-old birds were housed in cages arranged in clusters inside climatic chambers, where they remained 24 hours 
a day with the doors closed under comfort temperature $\left(24^{\circ} \mathrm{C}\right)$ for a pre-experimental period of 4 weeks, in order to adapt to the physical environment of cages and the climatic chamber. Two clusters of galvanised wire cages were placed in each chamber, with dimensions of $50 \times 33 \times 20 \mathrm{~cm}$ (width, depth and height, respectively), with four floors each and three cages per floor, totalling twelve compartments per cluster. The cages were equipped with trough-type feeders and individual drinkers were made up of hermetically sealed containers. The water was consumed through nipple drinkers and there were excreta-collecting trays under the floors.

After the pre-experimental period, the quails were distributed into the different treatments with homogeneous weight and egg production. One hundred and ninetytwo (192) birds were housed in a thermal comfort zone $\left(24^{\circ} \mathrm{C}\right)$ and the other 192 in an environment above this zone $\left(32^{\circ} \mathrm{C}\right)$, which was kept constant for a period of 12 hours daily ( 7 am to $7 \mathrm{pm}$ ). At $7 \mathrm{pm}$, at a room temperature of $22 \pm 2.0^{\circ} \mathrm{C}$, the doors were opened until 6:59 am the following morning, simulating the environmental conditions of semi-arid regions.

Water salinity levels were obtained by dissolving sodium chloride $(\mathrm{NaCl})$ in water from the local supply system (1.3 dS $\left.\mathrm{m}^{-1}\right)$. Four 200 $L$ drums were filled and the ECw reading was performed with a portable digital conductivity meter (model ITCD - 1000 of Instrutemp, São Paulo, SP, Brazil). Depending on the result, $\mathrm{NaCl}$ was dissolved and mixed until the solution reached the desired ECW level. Then, the amount of salt was determined based on the electrical conductivity of the water (ECw), according to Richards (1954).
During the entire experimental period, the birds were subjected to identical food management, receiving feed for laying quails based on corn and soybean meal. The nutritional composition of the feed ingredients was obtained based on charts by Rostagno et al. (2011). Water and feed were provided daily, manually and ad libitum. Leftovers and waste were weighed and discounted from the initial amount of feed.

The program adopted for lighting was 17 hours of light and 7 hours of darkness. At the beginning of the experiment, the average weight of the birds was $170 \pm 5$ grams (14 weeks old) and $228 \pm 5$ grams at the end (26 weeks old). The experimental phase was distributed into four periods of 21 days each. At the end of each period, four eggs per plot were separated, two to determine the weights $(\mathrm{g})$ and percentages (\%) of yolk, albumen, shell and shell thickness $(\mathrm{mm})$, and two to obtain specific gravity $\left(\mathrm{g} \mathrm{cm}^{-3}\right)$. In addition, twice a week, the physiological variables were measured: respiratory rate (FR), cloacal temperature (TC) and body surface temperature (Tsc). Two birds from each plot were chosen randomly, marked and identified, to ensure the same birds were used in the analysis from the beginning to the end of the experiment. The measurements were taken inside the climatic chamber so that there was no interference to the birds from the external environment.

The averages of the results were evaluated by means of analysis of variance (ANOVA) and, to compare the averages, the PROC GLM was used with the Tukey test, at a level of $5 \%$ probability, with the aid of the SAS 9.1 software. The effects of sodium levels were estimated by the PRO REG of Statistical Analyses System [SAS] (2001). 


\section{Results and Discussion}

There was no effect of the interaction $(P>0.05)$ between temperatures and water salinity levels on the physiological variables of birds; the increasing levels of salts in the water did not change $(P>0.05)$ the physiological variables of the quails. However, at $32^{\circ} \mathrm{C}$, there was an increase $(P<0.05)$ in respiratory rate, cloacal temperature, and body surface temperature of the birds (Table 1).

Table 1

Effect of water salinity levels and temperature on the physiological variables of Japanese quails in the production phase

\begin{tabular}{|c|c|c|c|c|}
\hline \multicolumn{2}{|l|}{ Effect } & $\begin{array}{l}\text { Respiratory rate } \\
\text { (mov/ } \mathrm{min})\end{array}$ & $\begin{array}{c}\text { Cloacal temperature } \\
\left({ }^{\circ} \mathrm{C}\right)\end{array}$ & $\begin{array}{l}\text { Surface temperatura } \\
\qquad\left({ }^{\circ} \mathrm{C}\right)\end{array}$ \\
\hline \multirow{4}{*}{$\begin{array}{l}\text { Salinity levels } \\
\quad\left(\mathrm{dS} \mathrm{m}^{-1}\right)\end{array}$} & 1.5 & 25.93 & 41.68 & 37.24 \\
\hline & 3.0 & 25.82 & 41.72 & 37.75 \\
\hline & 4.5 & 25.93 & 41.74 & 37.84 \\
\hline & 6.0 & 24.85 & 41.76 & 37.80 \\
\hline \multirow{2}{*}{$\begin{array}{c}\text { Temperature } \\
\left({ }^{\circ} \mathrm{C}\right)\end{array}$} & 24 & $24.92 b$ & $41.58 b$ & $35.94 b$ \\
\hline & 32 & $26.34 a$ & $41.87 a$ & $39.37 a$ \\
\hline \multicolumn{2}{|c|}{ MSE } & 1.22 & 0.14 & 0.59 \\
\hline \multicolumn{5}{|c|}{$P$-value } \\
\hline \multicolumn{2}{|c|}{ Salinity } & 0.1005 & 0.6174 & 0.0592 \\
\hline \multicolumn{2}{|c|}{ Temperature } & $<0.0003$ & $<0.0001$ & $<0.0001$ \\
\hline \multicolumn{2}{|c|}{ Temperature $x$ salinity } & 0.117 & 0.5739 & 0.1411 \\
\hline
\end{tabular}

Mean standard error= MSE; Averages followed by the same lowercase letter do not differ statistically by Tukey's test at $5 \%$ probability.

The respiratory frequency of quails exposed to the heated environment was higher. This is a protection mechanism that increases evaporation in the exhaled air and releases internal heat in the evaporative form to maintain body thermal balance (Rodrigues et al., 2016; Silva et al., 2017), but it can lead to production losses. S. M. Santos et al. (2014) reported this increase in the respiratory rate in quails kept at temperatures from 30 to $33^{\circ} \mathrm{C}$. However, the respiratory rate remained within limits for the species. As seen in the experiment, young birds can adapt to higher salt concentrations, increasing their water consumption and the excretion of ions, such as sodium and chloride, through the kidneys (Khalilipour et al., 2019).

The average cloacal temperature of the birds with the different levels of water salinity were within normal limits (Ribeiro et al., 2016), demonstrating that salinity levels of up to $6.0 \mathrm{dS} \mathrm{m}^{-1}$ do not modify this variable. At $32^{\circ} \mathrm{C}$, the cloacal temperature was higher. One of the problems with quail farming in semi-arid regions is heat stress and, since quails do not have sweat glands and their 
body is covered with feathers, they may have difficulty eliminating excess body heat. The cloacal temperature of birds can vary with age, weight, sex, physical activity, intake, and thermal environment. Cloacal temperatures were similar to those mentioned by Sousa et al. (2014) and Ribeiro et al. (2016), in research with quails kept in an environment with a temperature of $30.2 \pm 6^{\circ} \mathrm{C}$.

The salinity levels of the water did not affect the surface temperature of the birds since they use mechanisms to dissipate excess salt in the body, such as through urine and feces (Alahgholi et al., 2014). Furthermore, Lima et al. (2020) used increasing sodium levels in the feed (0.80 to $0.24 \%$ ) and found no nutritional disorders related to the level of sodium inclusion in the diets.

The birds subjected to heat stress showed higher surface temperatures $\left(34.3^{\circ} \mathrm{C}\right)$ and, under thermal stress, the birds increased the heat transmission from the body nucleus to the periphery of the body, stimulating blood flow to vascularised areas without feathers such as the ridges, dewlap and feet (Souza et al., 2013; Camerini, Silva, Nascimento, Oliveira, \& Souza, 2016).

No effect was observed on the interaction $(P>0.05)$ between temperatures and water salinity levels on egg quality. Except for shell thickness, which responded linearly to the increase in salinity, the other variables were not influenced by this factor. Environmental temperature influenced $(P<0.05)$ the weight of the eggs and shell and the percentage of shell. For shell thickness, a linear response was observed, that is, as the level of water salinity increased, the thickness of the shell decreased (Table 1).

Water consumption at different salinity levels did not change $(P>0.05)$ the weight of the eggs. Animals consuming excess minerals use mechanisms for excretion, such as increased urination containing high levels of minerals (such as sodium, chlorine and potassium) (Abdelsattar et al., 2020). Using increasing sodium levels $(0.10$ to $0.30 \%)$ in quail feed (Lima et al., 2020) did not observe effects on egg production and weight. At a temperature of $32^{\circ} \mathrm{C}$, the egg weight decreased by $3.3 \%$, however, this remained within the average and, at this temperature, the physiological variables were higher (Table 1), demonstrating the adaptive capacity of the birds to the hot environment and the thermal amplitude, as occurs in semi-arid regions. Akdemir et al. (2019) stated that egg production and weight were reduced in laying quails kept under cyclical heat stress $\left(7 \mathrm{~h}\right.$ at $\left.34 \pm 2^{\circ} \mathrm{C}\right)$, followed by thermal comfort ( $17 \mathrm{~h}$ at $22 \pm 2^{\circ} \mathrm{C}$ ).

Egg quality can be affected by the levels of salt in the water or feed. However, salinity levels of up to $6.0 \mathrm{dSm}^{-1}$ did not change the weight and percentage of albumen, which were similar to those reported by Lima et al. (2015) and Rodrigues et al. (2016). The latter papers did not find an effect of increasing sodium levels in the feed and electrolyte balance, respectively. At the highest temperature, there was a reduction $(0.26 \mathrm{~g})$ in the albumen weight, which can be justified by the correlation between egg and albumen weight, and egg weights were lower at $32^{\circ} \mathrm{C}$. Silva et al. (2017) and Akdemir et al. (2019) describe that the height and length of the albumen of quail eggs were affected by heat stress.

Water salinity and temperature levels did not alter the weight and percentage of the yolk. When analysing the effect of sodium levels in the feed, Lima et al. (2015) found no effects on weight and percentage of yolk. 
The increase of mineral levels in feed can improve eggshell quality but, even with higher levels of sodium and chlorine in the water, there was no significant difference $(P>$ 0.05 ) in the percentage of shells (Table 2). Quails are tolerant to high levels of chlorine in water but, in the laying phase, it can cause a reduction in the activity of carbonic anhydrase in the mucosa of the shell gland (Khalilipour et al., 2019). When using levels of increasing sodium levels in the feed of laying quails, Lima et al. (2020) did not observe changes in the percentage of yolk, albumin or eggshells.

\section{Table 2}

Effect of water salinity and temperature levels on quail performance

\begin{tabular}{|c|c|c|c|c|c|c|c|c|c|c|}
\hline \multicolumn{2}{|c|}{ Effect } & $\begin{array}{l}\text { EW } \\
\text { (g) }\end{array}$ & $\begin{array}{l}\text { AW } \\
\text { (g) }\end{array}$ & $\begin{array}{l}\text { PA } \\
\%\end{array}$ & $\begin{array}{l}Y W \\
(g)\end{array}$ & $\begin{array}{l}\text { YP } \\
\%\end{array}$ & $\begin{array}{l}\text { SW } \\
\text { (g) }\end{array}$ & $\begin{array}{l}\text { PS } \\
\%\end{array}$ & $\begin{array}{c}\mathrm{SG} \\
\left(\mathrm{gcm}^{-3}\right)\end{array}$ & $\begin{array}{l}\mathrm{ST} \\
(\mathrm{mm})\end{array}$ \\
\hline \multirow{4}{*}{$\begin{array}{l}\text { Salinity } \\
\text { levels } \\
\text { (dS m-1) }\end{array}$} & 1.5 & 12.02 & 6.46 & 53.79 & 3.95 & 33.15 & 1.01 & 8.41 & 1.07 & 224.66 \\
\hline & 3.0 & 12.11 & 6.48 & 53.45 & 3.96 & 32.67 & 1.02 & 8.43 & 1.07 & 229.69 \\
\hline & 4.5 & 12.04 & 6.40 & 53.13 & 3.92 & 32.58 & 1.02 & 8.48 & 1.06 & 213.59 \\
\hline & 6.0 & 11.97 & 6.40 & 53.79 & 3.85 & 32.20 & 1.01 & 8.47 & 1.07 & 215.08 \\
\hline \multirow{2}{*}{$\begin{array}{c}\text { Temperature } \\
\left({ }^{\circ} \mathrm{C}\right)\end{array}$} & 24 & $12.20 a$ & $6.56 a$ & 59.05 & 3.96 & 32.39 & $1.04 a$ & $8.56 a$ & 1.06 & 225.36 \\
\hline & 32 & $11.80 \mathrm{~b}$ & $6.30 \mathrm{~b}$ & 58.91 & 3.87 & 32.76 & $0.98 b$ & $8.33 b$ & 1.06 & 216.15 \\
\hline \multicolumn{2}{|l|}{ SEM } & 0.33 & 0.28 & 1.92 & 0.21 & 1.60 & 0.03 & 0.28 & 0.02 & 17.59 \\
\hline \multicolumn{11}{|c|}{$P$-value } \\
\hline \multicolumn{2}{|c|}{ Salinity } & 0.7629 & 0.8642 & 0.0827 & 0.6408 & 0.7896 & 0.7531 & 0.9154 & 0.2696 & 0.0911 \\
\hline \multicolumn{2}{|c|}{ Temperature } & $<0.0001$ & 0.0027 & 0.5311 & 0.1616 & 0.4208 & $<0.0001$ & $<0.0084$ & 0.7410 & 0.0770 \\
\hline \multicolumn{2}{|c|}{ Temperature $\mathrm{x}$ salinity } & 0.1870 & 0.2258 & 0.9158 & 0.1194 & 0.5810 & 0.3016 & 0.3052 & 0.9533 & 0.4675 \\
\hline
\end{tabular}

Mean standard error= MSE; Averages followed by the same lowercase letter do not differ statistically by Tukey's test at $5 \%$ probability; Egg weight $=\mathrm{EW} ;$ Albumen weight $=\mathrm{AW} ;$ Yolk weight $=\mathrm{YW}$; Shell weight $=\mathrm{SW} ;$ Percentage of albumen $=$ PA; Yolk percentage= YP; Percentage of shell =PS; specific gravity= SG; Shell thickness= ST.

The percentage of shells at $32^{\circ} \mathrm{C}$ had a reduction of $0.23 \%$ (Table 2). This may be related to the lower weight of the eggs which, in this environment, had a reduction of $0.41 \mathrm{~g}$ and an increase in respiratory rate, which may lead to respiratory alkalosis, interfering in egg quality. A higher percentage of shell in eggs can improve their quality, avoiding breakage during transport and marketing. On the other hand, the increase in the ambient temperature can cause a drop in the quality of the eggshells
(Ma et al., 2014), so that the bird increases breathlessness, decreasing the $\mathrm{CO}_{2}$ in the lungs, which can lead to respiratory alkalosis and results in less absorption of calcium and less efficiency in its use; this results in small and thin-shelled eggs (Akdemir et al., 2019).

The lower the specific gravity, the less thick the shell is, and this gravity was not influenced $(P>0.05)$ by the salinity levels of the water (Table 2). Lima et al. (2015) observed similar results in quail eggs when researching 
different levels of sodium in the feed.Schneider et al. (2016) did not observe differences in production, weight or specific gravity of eggs of laying hens consuming increasing levels of sodium (5 to $100 \mathrm{ppm}$ ). Specific gravity was not influenced by the ambient temperature (Table 2), with averages of $1.06 \mathrm{~g} \mathrm{~cm}^{-3}$, similar to those mentioned by Silva et al. (2017). Vercese et al. (2012) and Akdemir et al. (2019) found a significant reduction in the specific gravity of birds' eggs, when they were subjected to different thermal stress conditions.

For shell thickness, the best response was found at $0.227 \mathrm{~mm}$ at a level of $1.5 \mathrm{dSm}$ 1 , and the level of $6.0 \mathrm{dSm}^{-1}$ reflected the worst coefficient $(0.211 \mathrm{~mm})$, demonstrating that increases in water salinity level reduced the thickness of the egg shell. High levels of sodium chloride in the feed or water can reduce the quality of the eggshell, caused by reduced activity of carbonic anhydrase in the mucosa of the shell gland. Assunção, Martins, Lima, Martins and Souza (2017), when working with sodium levels in the feed of semi-heavy layers, found that the thickness of the eggshell decreased with the highest level of sodium in the feed.

Temperature rises can alter the physiology and metabolism of laying birds, adversely affecting the eggshell. However, the temperature of $32^{\circ} \mathrm{C}$ for $12 \mathrm{~h}$ daily did not affect $(P>0.05)$ the thickness of the shell (Table 2), corroborating Vercese et al. (2012), who did not obtain significant results in the thickness of the shell when the temperature was raised from 30 to $36^{\circ} \mathrm{C}$, in different environmental situations.

Quails can be raised under higher temperature conditions and consume saline water. In the present experiment, the birds were subjected to the heat temperature for 12 hours, alternating with the lower ambient temperature for 12 hours, as occurs in tropical climates. This helps in the recovery of birds and reflects in the ingestive behaviour because quails may have eaten more during this period, which in turn, reflects in the production and quality of eggs, and the animals adapted to chronic stress, showing additional gain in their performance (Akdemir et al., 2019).

\section{Conclusions}

Except for shell thickness, water salinity levels did not promote changes in egg quality, respiratory rate, and cloacal and surface temperature, which were higher under stress temperatures. However, as the temperature increased, there was a slight reduction in egg weight, shell and percentage of shell. Laying quails can receive water with salinity levels of up to $6.0 \mathrm{dS} \mathrm{m}^{-1}$ and be raised in an environment with temperatures of up to $32^{\circ} \mathrm{C}$, for a daily period of up to 12 hours.

\section{References}

Abdelsattar, M. M., Hussein, A. M. A., Abd ElAti, M. N., \& Saleem, A. M. (2020). Impacts of saline water stress on livestock production: a review. International Journal of Agricultural Science, 2(1), 1-12. doi: 10. 21608/svuijas.2020.67635

Akdemir, F., Köseman, A., \& Şeker, I. (2019). Alchemilla vulgaris effects on egg production and quality expressed by heat stressed quail during the late laying period. South African Journal of Animal Science, 49(5), 857-868. doi: 10.4314/ sajas.v49i5.8 
Alahgholi, M., Tabeidian, S. A., Toghyani, M., \& Fosoul, S. S. A. S. (2014). Effect of betaine as an osmolyte on broiler chickens exposed to different levels of water salinity. Archive Tierzucht, 57(1), 1-12. doi: 10.7482/0003-9438-57-004

Assunção, A. S. A., Martins, R. A., Lima, H. J. D., Martins, A. C. S., \& Souza, L. A. Z. (2017). Sodium levels in the diets of semi-heavy laying hens reared in a hot climate after peak lay. Boletim da Indústria Animal, 74(1), 36-44. doi: 10.17523/bia.v74n1p36

Camerini, N. L., Silva, R. C., Nascimento, J. W. B., Oliveira, D. L., \& Souza, B. B. (2016). Variação da temperatura superficial de aves poedeiras criadas em dois sistemas de criação utilizando termografia. Agropecuária Científica no Semiárido, 12(2), 145-152. doi: 10.30969/acsa.v12i2. 665

El-Tarabany, M. S. (2016). Impact of temperature-humidity index on egg-laying characteristics and related stress and immunity parameters of japanese quails. International Journal of Biometeorology, 60(7), 957-964. doi: 10.1007/s00484-0 15-1088-5

Freitas, E. R., Farias, N. N. P., Nascimento, G. A. J., Rodrigues, A. M., Queiroz, M. G. R., Raquel, D. L., \& Lima, R. C. (2013). Parâmetros sanguíneos e ósseos de codornas de corte alimentadas com diferentes níveis de sódio. Semina: Ciências Agrárias, 34(2), 845-852. doi: 10.5433/1679-0359.2013v34n2p845

Guimarães, M. C. C., Furtado, D. A., Nascimento, J. W. B., Tota, L. C. A., Silva, C. M., \& Lopes, K. B. P. (2014). Effect of season on production performance of quail in the semiarid region of Paraiba state, Brazil. Revista Brasileira de Engenharia Agrícola e Ambiental, 18(2), 231-237. doi: 10.1590/ S1415-43662014000200015

Khalilipour, G., Maheri, N. S., \& Shaddel, A. T. (2019). Effects of saline drinking water on growth performance and mortality rate of japanese quails (Coturnix coturnix Japonica). Journal Agricultural National, 22(6), 942-947. doi: 10.18016/ ksutarimdoga.vi.553366

Lima, H. J. D., Barreto, S. L. T., Paula, E., Dutra, D. R., Costa, S. L., \& Abjaude, W. S. (2015). Níveis de sódio na ração de codornas japonesas em postura. Revista Brasileira de Saúde e Produção Animal, 16(1), 73-81. doi: 10.1590/S1519-9940 2015000100009

Lima, H. J. D., Morais, M. V. M., \& Barreto, S. L. T. (2020). Japanese laying quail. Research, Society and Development, 9(6), 1-4. doi: 10.33448/rsd-v9i6.2486

Ma, X., Lin, Y., Zhang, H., Chen, W., Wang, S., Ruan, D., \& Jiang, Z. (2014). Heat stress impairs the nutritional metabolism and reduces the productivity of egg-laying ducks. Animal Reproduction Science, 145(3-4), 182-190. doi: 10.1016/j.anire prosci.2014.01.002

Petrucci, F. B., Bonaparte, T. P., Scottá, B. A., Vargas, J. G., Jr., Vieira, D. V. G., \& Marin, J. F. V. (2017). Sodium levels in food of Japanese quail in the laying phase. Revista Verde de Agroecologia e Desenvolvimento Sustentável, 12(2), 338342. doi: 10.18378/rvads.v12i2.4391 
Raquel, D. L., Lima, R. C., Freitas, E. R., Sá, N. L., Xavier, R.P.S., \&Paiva, A. C. (2011). Níveis de sódio para codornas italianas destinadas à produção de carne. Revista Brasileira de Zootecnia, 40(1), 135-141. doi: 10.1590/ S1516-35982011000100019

Ribeiro, T. L. A., Souza, B. B., Brandão, P. A., Roberto, J. V. B., Medeiros, T. T. B., Silva, J. J., \& Carvalho, J. E. M., Jr. (2016). Different levels of protein and energy on physiological behavior and performance of European quail in the Brazilian semiarid. Journal of Animal Behaviour and Biometeorology, 4(3), 76-83. doi: 10.14269/2318-1265/jabb.v4n3p76-83

Richards, L. A. (1954). Diagnosis and improvement of saline and alkali soils. Washington: USDA Agricultural Handbook.

Rodrigues, L. R., Furtado, D. A., Costa, F. G. P., Nascimento, J.W.B., \& Cardoso, E. A. (2016). Thermal comfort index, physiological variables and performance of quails fed with protein reduction. Revista Brasileira de Engenharia Agrícola e Ambiental, 20(4), 378-384. doi: 10.1590/1807-1929/ agriambi.v20n4p378-384

Rostagno, H. S., Albino, L. F. T., Donzele, J. L., Gomes, P. C., Oliveira, R. F., Lopes, D. C.,... Euclides, R. F. (2011). Brazilian tables for poultry and swine - composition of feedstuffs and nutritional requirements (3nd ed.). Viçosa, MG: UFV.

Santos, S. M., Tinôco, I. F. F., Barreto, S. L. T., Amaral, A. G., Pires, L. C., \& Ferreira, A S. (2014). Determination of upper limits of the thermal comfort zone for quails acclimatized in Brazil 22-35 days old. Revista Brasileira de Saúde e Produção
Animal, 15(2), 350-360. doi: 10.1590/ S1519-99402014000200019

Santos, T.C., Gates, R.S., Tinôco, I. F.F.,Zolnier, S., \& Baêta, F. C. (2017). Behavior of Japanese quail in different air velocities and air temperatures. Pesquisa Agropecuária Brasileira, 52(5), 344-354. doi: 10.1590/ s0100-204x2017000500008

Schneider, A. F., Almeida, D. S., Moraes, N. A., Picinin, L. C. A., Oliveira, V., \& Gewehr, C. E. (2016). Chlorinated drinking water for lightweight laying hens. Arquivo Brasileiro de Medicina Veterinária e Zootecnia, 68(6), 1690-1696. doi: 10.1590/1678-41 62-8795

Scottá, B. A., Bonaparte, T. P., Vargas, J. G., Jr., Petrucci, F. B., Vieira, V. G. D., Marin, J. F. V.,... Soares, R. T. R. (2017). Sodium and potassium at different levels of crude protein for laying quais. Revista Agrarian, 10(35), 76-83. doi: 10.30612/agrarian.v10i 35.4437

Silva, R. C., Nascimento, J. W. B., Rodrigues, L. R., Leite, P. G., Galvão, T., Sobrinho, \& Furtado, D. A. (2017). Quality of quail eggs confined in thermoneutral environment and heat stress. Journal of Animal Behaviour and Biometeorology, 5(4), 139-143. doi: 10.31893/2318-1265jabb. v5n4p139-143

Sousa, M. S., Tinôco, I. F. F., Barreto, S. L. T., Amaral, A. G., Pires, L. C., \& Ferreira, A. S. (2014). Determination of upper limits of the thermal comfort zone for quails acclimatized in Brazil 22-35 days old. Revista Brasileira de Saúde e Produção Animal, 15(2), 50-360. doi: 10.1590/S15 19-99402014000200019 
Souza, J. B. F., Jr., Queiroz, J. P. A. F., Domingos, H. G. T., Torquato, J. L., Sá, G. F., Fo. de, \& Costa, L. L. M. (2013). Avaliação termográfica de codornas japonesas (Coturnix coturnix japonica). Journal of Animal Behaviour and Biometeorology, 1(2), 61-64. doi: 10.14269/2318-1265. v01n02a05

Statistical Analyses System (2001). Statistical analysis system user's guide. Version 9.1. Cary: Statistical Analyses System Institute.
Vercese, F., Garcia, E. A., Sartori, J. R., Silva, A. P., Faitarone, A. B. G. I., Berto, D. A. I.,... Pelícia, K. (2012). Performance and egg quality of Japanese quails submitted to cyclic heat stress. Brazilian Journal of Poultry Science, 14(1), 37-41. doi: 10.1590/S1516-635X2012000100007 
